\title{
A microvascularis coronariabetegség diagnosztikája és kezelése A magyarországi helyzet sajátosságai
}

SZAUDER IPOLY

Az invazív vizsgálatok azt mutatják, hogy a betegek kétharmadában a szívizom-ischaemia obstruktív coronariabetegség és más szívbetegség hiányában (INOCA) áll fenn, melynek oka a microvascularis diszfunkció (CMD), és amelynek következménye a microvascularis koszorúér-betegség (MVD), a microvascularis vagy epicardialis vasospasticus angina (MVA) lehet. A korszerú klinikai gyakorlatban a noninvazív kardiológiai képalkotó eljárások fejlődésével lehetővé vált a coronariaáramlás mérése a jellemzó indexek meghatározásával. Mindezek javítják a CMD és az általa okozott myocardialis ischaemia diagnózisát, és lehetôséget adnak az elsődleges MVD diagnosztizálására. Tekintettel arra, hogy az MVD felismerése-kezelése a magyar orvosi gyakorlatban jelentôsen alulreprezentált, az alábbiakban részletesen ismertetjük a primer stabil microvascularis anginát (MVA), annak korszerú invazív és noninvazív differenciáldiagnózisát és kezelését, különös tekintettel - a gyakorisága miatt - a magas vérnyomás által kiváltott formára és a nôk koszorúér-betegségére. Kiemeljük a hazai lehetôségek figyelembevételével az ajánlható diagnosztikai eljárásokat.

INOCA, microvascularis diszfunkció, microvascularis coronariabetegség, microvascularis angina pectoris, hypertoniás szívbetegség, nók ischaemiás szívbetegsége

\author{
DIAGNOSIS AND TREATMENT \\ OF MICROVASCULAR CORONARY \\ HEART DISEASE. SPECIALITIES \\ OF CONDITIONS IN HUNGARY
}

Invasive investigations show that in twothirds of patients the myocardial ischaemia persists without obstructive coronary disease and any other heart conditions (INOCA). The underlying cause may be microvascular dysfunction (CMD) with consecutive microvascular coronary disease (MVD) and microvascular or epicardial vasospastic angina (MVA). The modern practice of clinical cardiology while using the developed non-invasive cardiac imaging permits exact measuring of the coronary flow with its characteristic indices. All of these improve the diagnosing of CMD-induced myocardial ischemia and provide opportunity to determine primary MVD cases. Since the recognition and treatment of MVD is significantly underrepresented in the Hungarian medical care, the primary stable microvascular angina (MVA) is described in detail below with its modern invasive and non-invasive differential diagnosis and treatment, concerning especially its frequency provoked by high blood pressure and female coronary heart diseases. There are highlighted all recommended diagnostic procedures available under domestic conditions.

INOCA, microvascular dysfunction, microvascular coronary heart disease, microvascular angina,

hypertensive cardiac disease, female coronary heart disease

\begin{abstract}
dr. SZAUDER Ipoly (levelezési cím/correspondence): Kardiológiai Diagnosztikai és Hypertonia Központ/Cardiology Diagnostic and Hypertension Center, H-1015 Budapest, Ostrom u. 27. E-mail: drszauderipoly@gmail.com
\end{abstract}

Érkezett: 2020. október 11. Elfogadva: 2021. január 1.

https://doi.org/10.33616/lam.31.001

A $\mathrm{z}$ angina pectorisra panaszkodó és a noninvazív vizsgálatok alapján bizonyíthatóan szívizom-ischaemiában szenvedó betegeknél a koronarográfiák mintegy 60-70\%-ában nem mutatható ki obstruktív koszorúér-betegség. Ezt a percutan cardiovascularis beavatkozá- sok európai szövetsége (EAPCI) és az Európai Kardiológus Társaság (ESC) is kiemeli, hangsúlyozva a nem obstruktív koszorúerekkel járó ischaemia (INOCA) fontosságát $(1,2)$. A korábbi szemlélettel ellentétben, ez nem jóindulatú, és kezeletlenül éppoly - különösen nókben gya- 


\section{RÖVIDÍTÉSEK}

ABPM: 24 órás ambulans vérnyomásmonitor

ACBG: coronariabypass-mútét

ACE: angiotenzin konvertáló enzim

ACEI: angiotenzin konvertáló enzim gátló

ACS: akut coronariaszindróma

$\mathrm{ADH}$ : antidiuretikus hormon

ARB: angiotenzin receptor blokkoló

AT: angiotenzin

ATP: adenozin-trifoszfát

CAD: coronaria-szívbetegség

cAMP: ciklikus adenozin-monofoszfát

CBF: coronaria-vérátáramlás

CCTA: Coronary Computed Tomography Angio graphy - kardio-CT

CFR: coronariaátáramlási tartalék (rezerv)

cGMP: ciklikus guanozin-monofoszfát

CK-MB: MB típusú kreatininkináz

CMR: cardiovascularis mágnesrezonancia

CMD: coronaria microvascularis diszfunkció

CSX: coronaria X-szindróma

CPT: cold pressor teszt

CRP: C-reaktív protein

CTFFR: CT-vel meghatározott frakcionált áramlási tartalék

CVR: coronaria vascularis rezisztencia

EAPCI: percutan cardiovascularis beavatkozások európai szövetsége

EDHF: endotheliumból származó hiperpolarizáló faktor ET: endotelin
ESC: Európai Kardiológus Társaság

FFR: frakcionált áramlási tartalék

FMD: áramlás mediálta dilatáció

GP II/b/III/a: glikoprotein II/b/III/a

GTP: guanozin-monofoszfát

HCM: hypertrophiás cardiomyopathia

INOCA: nem obstruktív koszorúereknél észlelt ischaemia

MBF: myocardialis véráramlásképalkotás

MPI: myocardialis perfúziós képalkotás

MVA: microvascularis angina

MVD: microvascularis coronaria betegség

MVO: microvascularis obstrukció

NO: nitrogén-(mon) oxid

NSTE: nem ST-elevációs myocardialis infarktus

PCI: percutan coronaintervenció

PET: pozitronemissziós tomográfia

PTP: coronariabetegség preteszt

valószínüsége

RAAS: renin-angiotenzin-aldoszteron rendszer

SPECT: single photon emission computer tomography, szívizotóp-vizsgálat

STEMI: ST-elevációs myocardialis infarktus

TEE: transoesphagealis echokardiográfia

TIMI: thrombolysis in myocardial infarction

TNI: troponin I

TNT: troponin T

TNF: tumornekrózis-faktor

TTE: transoesophagealis echokardiográfia koribb - súlyos szövődményekhez (szívinfarktus, szívelégtelenség stb.) vezethet, mint az obstruktív coronariabetegség. A koszorúerek microvascularis diszfunkciója (CMD) és az ennek következtében kialakuló microvascularis coronariabetegség (MVD), microvascularis angina pectoris (MVA) még mindig jelentôsen alulreprezentált a hazai orvosi (kardiológiai) gyakorlatban. A koronarográfián átesett hazai betegek mintegy 50\%-ában a zárójelentésben csupán a negatív koronarográfia szerepel, hiányzik a diagnózisokból a microvascularis coronariabetegség felvetése, illetve az erre irányuló, ezt megerősítő invazív indexek és a noninvazív vizsgálatok, az adekvát terápia kijelölése-indikálása. Igy a témában kevésbé jártas kardiológus vagy kezelôorvos a negatív koronarográfia láttán nem kezeli-követi megfelelóen az MVD-s betegeket, ezért, mint az EAPCI-ajánlás írja: „...a klinikusok tájékozatlanságának csökkentése szükséges, ezzel lehetne megszüntetni az INOCA terápiás nihilizmusát” (2). A noninvazív kardiológiai képalkotó eljárások fejlódésével lehetővé vált a coronariaáramlás mérése a korszerú klinikai kardiológiai gyakorlat számára a jellemzó indexek meghatározásával: a koszorúér-áramlási tartalék (CFR), a coronariavérátáramlás $(\mathrm{CBF})$, a szívizom-véráramlás $(\mathrm{MBF})$, a microvascularis rezisztencia indexe (IMR), a frakcionált áramlási tartalék (FFR). Mindezek javítják a CMD diagnózisát, és lehetőséget adnak az elsődleges MVD diagnosztizálására.

Az elsődleges MVD-MVA heterogén betegcsoportokat foglal magába a microvascularis diszfunkció különböző patogenetikai és patofiziológiai mechanizmusaival, a tünetek széles spektrumával, eltérő klinikai következményekkel, ezért eltérő diagnosztikai és terápiás megközelítésekre van szükségük.

A közlemény célja egy rövid elméleti bevezetés után az MVD-MVA mint igen összetett és nem egyszerúen diagnosztizálható kórkép klinikumának a megismertetése, valamint vezérfonalat adni a hazai gyakorlat számára a felismeréstől a kezelésig, különös tekintettel az obstruktív coronariabetegség nélküli, elsődleges formájára. Mint minden más kórképre, erre is igaz: a rendelkezésre álló irányelvek mellett a gyakorlat próbája dönti el orvosi tevékenységünk sikerességét. 


\section{A coronariakeringés funkcionális anatómiája}

A szívizom vérellátása, különös tekintettel a microvascularis coronariakeringésre

Epicardialis erek: nagy kapacitásúak, kis ellenállásúak, proximalisan helyezkednek el, tágulékonyak, szisztolé alatt megnövekedett vértartalmukkal (mely akár $+25 \%$ is lehet), rugalmasságukkal elasztikus energiát tárolnak, ez alakul át mozgási energiává a diasztolé kezdetén, amikor megnyílnak a szisztolé alatti szúk, akár zárt intramyocardialis erek. Átmérőjük néhány millimétertől $500 \mu \mathrm{m}$-ig, koronarográfiával jól láthatóak. A prearteriolák és az arteriolák alkotják a microvascularis rendszert.

Prearteriolák: a proximalisak felelősek az áramlás-, míg a distalisak a nyomásváltozásokért: ha a perfúzió vagy a nyomás változik, megfelelő szúküléssel tartják fenn a nyomást az arteriolákban. Nem állnak a diffúzibilis myocardialis metabolitok kontrollja alatt.

$\mathrm{Az}$ arteriolák szintjén jelentôs a nyomásesés. Tónusukat a szívizom metabolizmusa során keletkező anyagok befolyásolják. Átmérőjük kisebb, mint $100 \mu \mathrm{m}$, koronarográfiával nem ábrázolódnak, ezért indirekt módon, nyomásméréssel detektálhatóak, valamint múködési zavaruk különböző képalkotó módszerekkel ismerhetô fel (1-4) (1. ábra).

\section{Myocardialis ischaemia - angina pectoris}

Szívizom-ischaemia alakul ki, amennyiben a szívizom oxigénigényét a koszorúér-vérellátás nem tudja kielégíteni. Ilyenkor a szívizomsejtek aerob anyagcseréje anaerob irányba tolódik el a mechanikai és az elektromos funkciók progresszív károsodásával. A myocardialis ischaemia leggyakoribb klinikai megnyilvánulása az angina pectoris, amit a koszorúerekben és a szívizomban lévô szenzoros (afferens) idegvégződések kémiai és mechanikai stimulálása okoz. Az adenozin lehet az anginás fájdalom fő kémiai közvetítôje, ugyanis az ischaemia során az ATP adenozinná bomlik le, amely az extracelluláris térbe történó diffundálás után okozza az anginás fájdalmat azáltal, hogy stimulálja a szív afferens idegvégződéseiben az A1-receptorokat. A szívizom-ischaemiát okozhatja az epicardialis (konduktív) koszorúerek fix és/vagy dinamikus szúkülete vagy a coronaria-mikrocirkulációt alkotó microvascula-

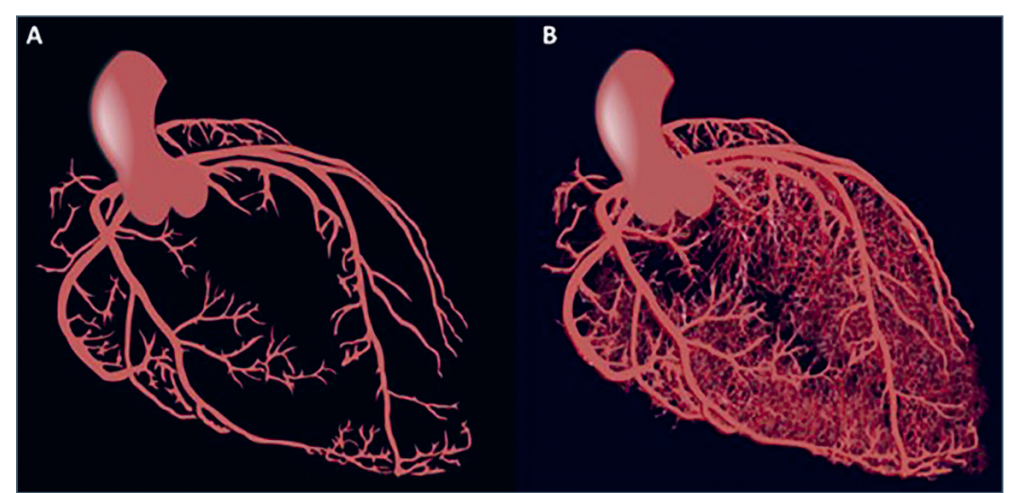

1. ábra. A: epicardialis coronariák, B: a teljes coronariarendszer microvascularis erekkel (Taqueti után)

ris rezisztenciaerek kóros állapota: constrictiója vagy a vasodilatatiójuk elmaradása, valamint - különbözô okokból - a vér oxigénszállító képességének csökkenése (1-8).

\section{A myocardialis ischaemia microvascularis coronariabetegségben}

A myocardialis ischaemia kialakulásában különbségek vannak az epicardialis és a microvascularis eredetû perfúziós zavar-deficit következtében. Az epicardialis (konduktív) erek szúkületekor a csökkent perfúzió következtében a szívizomischaemia homogén módon oszlik meg azokban a szívizomrészekben, amelyeket a szúkült artéria perfundál (2. ábra), és ami a kontraktilis funkció kimutatható szegmentális károsodását-mozgászavarát eredményezi. Microvascularis eredetû́

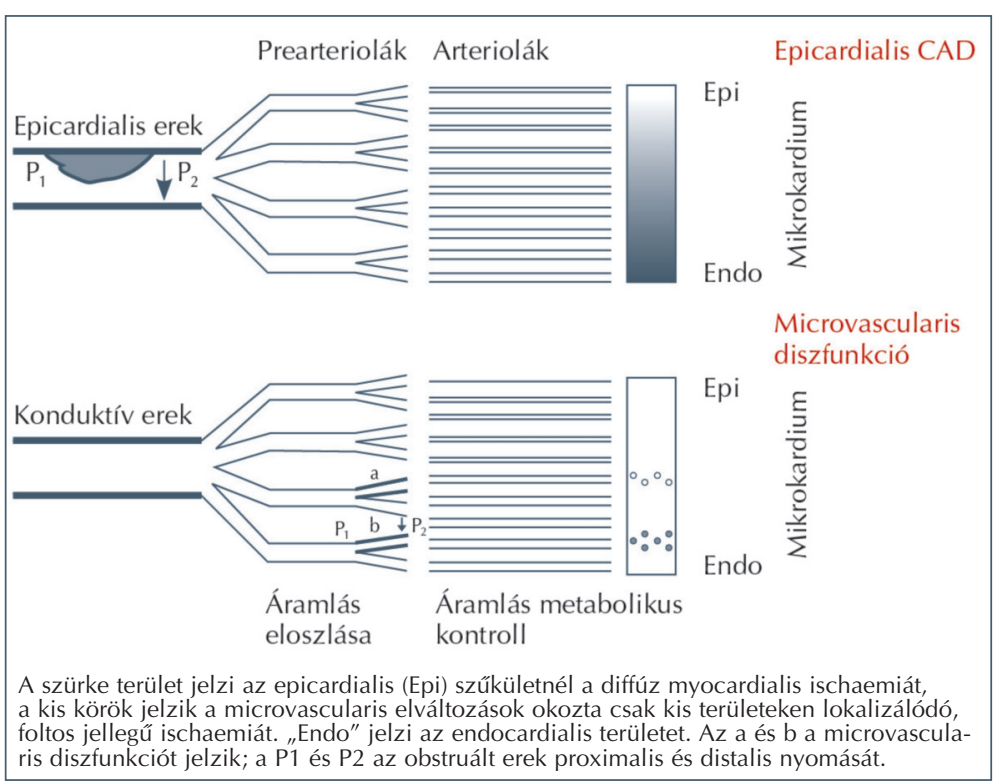

2. ábra. Az epicardialis és a microvascularis vérellátás: az áramlás és metabolikus kontrolljának sematikus rajza (Lanza után) 
elváltozások esetén a myocardialis ischaemia - amely többnyire a subendocardialis régiót érinti - csak kis myocardialis területekre lokalizálódik, mintegy foltosan helyezkedik el a myocardiumban, ezért nem jár kimutatható kontraktilitási eltéréssel, mert az ugyanezen a területen lévő, normális kontraktilitású szívizomsejtek múködése ezt elfedi. A ritkán foltonként, mintegy szigetszerúen elhelyezkedő ischaemiás területekből felszabaduló metabolitok nem mutathatóak ki a sinus coronarius vérében, mert a normális vérellátású myocardialis területekről érkezó nagyobb áramlásban felhígulnak. Mivel a CMD nem szegmentális, hanem szigetszerúen, az egész bal kamrai myocardiumot (gyakrabban a subendocardiumot) érinti, az MVA-betegeknél a rutin klinikai gyakorlatban alkalmazott, az epicardialis coronarierek perfúziós területét mutató módszerek (EKG, echokardiográfia, szívizomszcintigráfia) segítségével gyakran nem lehet az ischaemiát objektív módon igazolni. Ma még az általános gyakorlat az, hogy speciális invazív mérésekkel igazolják az MVD-t, de az újabb ajánlások szerint ezek kiválthatóak megfelelő noninvazív eljárásokkal.

A 2. ábrán ismertetjük a szívizom epicardialis és microvascularis vérellátását az áramlás és metabolikus kontrolljának sematikus rajzával (1-9).

\section{A szívizom véráramlására ható nyomási tényezôk}

Szisztolé alatt a bal kamra kontrakciója komprimálja az intramyocardialis ereket, valamint retrográd irányú áramlás is észlelhető, elsősorban az intramuralis és a kis epicardialis erekben, ezért a diasztolé alatt történik a myocardium érdemi vérellátása, melyet még vasodilatator és vasoconstrictor hatások is szabályoznak. Kóros állapotokban, amikor az arteriolák nyomása kisebb az aortáénál (például balkamra-hypertrophia, coronariastenosis vagy aortastenosis), és a diasztolé is rövidebb, az endocardium perfúziója korábban károsodik, mint az epicardiumé, mert érzékenyebb a csökkent perfúzióra. Erre jelentốs hatást gyakorolnak egyéb tényezốk is: autoreguláció (mely a distalis prearteriolák miogén válasza a véráramlás konstansan tartására), az autonóm idegrendszer, az endotheldiszfunkció, az endotelin, a kallikrein-kinin rendszer, a renin-angiotenzin-aldoszteron rendszer (RAAS), az adipocitokininek, a hormonális szabályozás. Kiemelendó az artériás hypertonia szerepe, ugyanis jelentôsen befolyásolhatja a perifériás keringést, mivel hatására a prearteriolák-arteriolák átépülése, a falvas- tagság-lumen arányának az eltolódása jön létre, valamint vasoconstrictio, amelyek miatt a myocardium oxigénigényét fokozó perifériás vascularis rezisztencia is megnövekszik.

A korábbi nézetekkel ellentétben, a coronariák nem végartériák, az intercoronariás kollaterálisok igen fontos szerepet töltenek be a microvascularis keringésben. Ezek szöveti hypoxia következményeként felszabaduló kémiai mediátorok, és a megnőtt nyírófeszültség miatt kialakuló nyomásgrádiens hatására jönnek létre a már meglévő anastomosisos csatornákból (20-200 $\mu \mathrm{m}$ átmérôjú, vékony falú struktúrák) úgynevezett arteriogenesises folyamat révén (melynek tisztázása valószínúleg a genetikai determináció megfejtése révén lehetséges) (1-10).

\section{A szívizom véráramlását befolyásoló egyéb tényezők}

Nyíróerố: az érfalra hatva károsíthatja a vérelemek és az endothelium közötti interakciót.

Endotheldependens vasodilatatio: gyakran az áramlás növekedésével összefüggô vasodilatatio "flow mediated dilatation - FMD”-ként szerepel. Az áramlás gyorsulásakor az ép artériák normális múködésú endothelsejtjeiből, a megnövekedett érfali nyíróerőre válaszként, fokozódik a nitrogén-monoxid (NO), az endotheldependens hiperpolarizációs faktor (EDHF) és a prosztaciklin felszabadulása, amelyek vasodilatatiót okoznak. A prosztaciklin hatása csekélyebb mértékú, szerepe akkor van, ha az endotheldiszfunkció miatt a NO elérhetôsége (biológiai felhasználhatósága) csökken (2-12).

\section{A myocardium oxigénfogyasztását meghatározó tényezők}

Átlagos coronaria vascularis rezisztenciánál és áramlásnál az idegvégződések által termelt moduláló hatású neurotanszmitterek széles köre, valamint az érfal által termelt autacoidok (ezek lokális hormonok vasoconstrictor, illetve vasodilatativ tulajdonsággal) a fô tényezók. Az endothel által termelt autacoidok: NO, prosztaglandinok, $\mathrm{EDHF}$, endotelin. Az adventitia által termeltek: hisztamin, kininek, leukotriének. A keringó thrombocytákból kibocsátottak: tromboxán A2, szerotonin. A szíffekvencia kétszeres emelkedése az $\mathrm{O}_{2}$-fogyasztást is megkétszerezi. A szív elöés utóterhelésének (preload és afterload) fokozódása jelentôsen növeli az $\mathrm{O}_{2}$-fogyasztást. Aortanyomás: 75-ről 175 Hgmm-re emelkedése kétszeres $\mathrm{O}_{2}$-fogyasztást jelent. A myocardium inotróp állapotának a fokozódása: például a posztext- 
raszisztolés potenciálás megduplázza a szívizom oxigénfogyasztását (2-11).

\section{A szimpatikus idegrendszer szerepe}

Megnövekedett aktivitása a vérnyomás-emelkedés meghatározó tényezője. Mai tudásunk szerint a szimpatikus idegrendszer fokozott aktivása játssza az egyik fő szerepet a hypertonia előidézésében és fenntartásában. $\alpha$-adrenoceptor vasoconstrictio: a szimpatikus idegrendszeri hatás aktiválódása következtében a szívfrekvencia és a szívizom kontraktilitása nő, mindkettô emeli a szívizom oxigénigényét és fogyasztását, mérsékelten, de általános kiterjedtséggel csökkenti a coronariaáramlást. $\beta$ adrenerg vasodilatatio: amikor a szimpatikus aktivitás (noradrenalin) az $\alpha$-adrenoceptorokon vasoconstrictiót idéz elő, a közepes és nagy coronariákon a $\beta$-adrenerg receptorok vasodilatatiót hoznak létre, csökkentve ezzel a vascularis rezisztenciát, növelve a vérátáramlást (2-14).

\section{Renin-angiotenzin-aldoszteron rendszer (RAAS)}

RAAS-hatások: a vesében keletkezô renin hatására az angitenzinogénből angiotenzin I hasad le, amelyből a keletkező angiotenzin II (AT II) konstriktív hatású a rezisztenciaerekre. Az AT II további hatásai az aldoszteron szintézisének és szekréciójának a növelése, a vesében a nátriumreabszorpció fokozása (direkt és aldoszteron hatáson keresztül), a renin kiáramlásának a gátlása, az $\mathrm{ADH}$ (antidiuretikus hormon) kiáramlásának a stimulációja és a szimpatikus tónus növelése, valamint a sejtek növekedését elősegítő és mitogen hatás, amelyek kedvezőtlen következményekkel járó sejthyperplasiát és hypertrophiát is indukálhatnak, növelve a perifériás vascularis rezisztenciát és vasoconstrictiót okoznak. Az AT II-szint emelkedése növeli az endothelsejtben a plazminogén aktivátor inhibitor-1 (PAI-1) expresszióját, ezzel egyidejúleg a bradikinin lebomlása (ACE mediálta reakció) az endothelsejt tPA(szöveti típusú plazminogén aktivátor) termelését csökkenti, amelyek thrombogen hatásúak (2-4, 8-11).

\section{Endotheldiszfunkció}

A NO az endothelialis sejtekból szabadul fel a vérnyomásváltozás, az áramlási sebességgel összefüggő nyíróerôk változásának a hatására. A NO igen hatékony vasodilatator, amely gátolja a thrombocyták adhézióját és aggregációját, gátolja a vascularis simaizomsejtek migrációját és proliferációját, antiinflammatorikus hatású, bio-

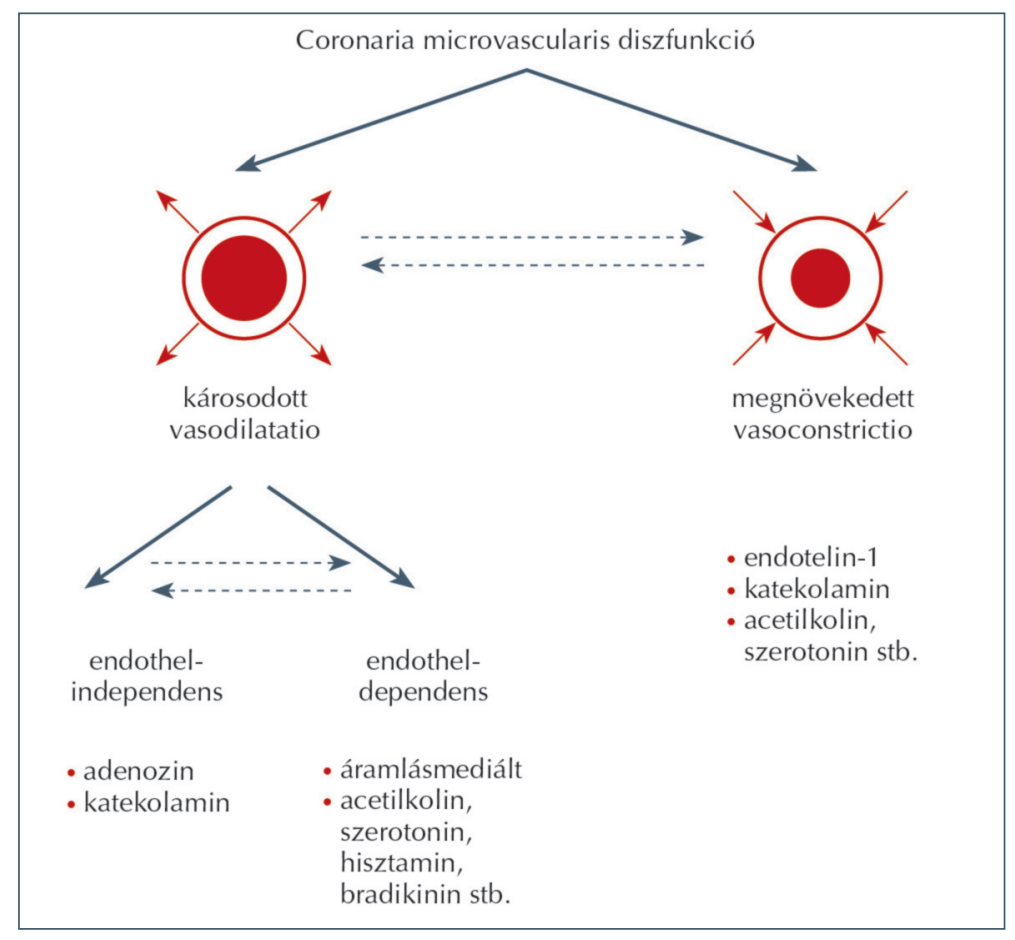

3. ábra. A microvascularis diszfunkció fó tényezői (Crea után)

lógiai barriert képez. A NO-termelés és -kibocsátás az endothelium mediálta vasodilatatio legfontosabb mechanizmusa, mely legelőször károsodik endotheldiszfunkció esetében.

Endotelin: az ET1 izoform jelentős szerepet játszik a cardiovascularis rendszerben létrejövő vasoconstrictióban: ezt a vascularis simaizomsejtek ET-A- és ET-B-receptoraihoz kötődése okozza, míg az endothelialis sejtek ET-B-receptoraihoz kötődése vasodilatatiót hoz létre.

Kallikrein-kinin rendszer: a RAAS-sal párhuzamosan múködve bizonyos funkcióiban az angitenzinogén II-vel és az aldoszteronnal ellentétes hatású. A kininek a B2-receptoron keresztül segítik elő a vasodilatator, a natriureticus és antitrophicus anyagok képződését (a B2-receptorok közvetett módon - AT1-R-receptor-hatás), gátolják az endothelialis NO termelődését, ezzel idézve elő a cardiovascularis hatásokat.

Adipocitokinek: a zsírszövet által kiválasztott biológiailag aktív anyagok a leptin és az adiponektin. A leptin fontos szerepet játszik az obesitassal összefüggó multiplex aterogenetikus folyamatok elóidézésében, proliferatív, proinflammatorikus, prothromboticus és prooxidans hatása révén. A krónikus hyperleptinaemia a károsodott vasodilatatión és a megnövekedett vasoconstrictio révén emeli a vérnyomást. Ezzel ellentében az adiponektinnek, mely az obesitasban alulregulált, védőszerepe van a cardiovascularis atheroscleroticus folyamatokban $(2-4,6-12)$. A legfőbb tényezőket a 3. ábra szemlélteti. 


\section{A microvascularis diszfunkció - a coronariabetegség (MVD-CMD) mechanizmusa}

Strukturális eltérések: Elsősorban a hypertonia, valamint a hypertrophiás cardiomyopathia (HCM) okozta balkamra-hypertrophia az intramuralis coronariák kedvezótlen átépülését („remodellingjét”) okozva növeli a coronariák vascularis rezisztenciáját (CVR) és csökkenti a coronariaáramlási tartalékot (CFR) $(2-4,6,10)$.

Funkcionális eltérések: az

Microvascularis eredetú elváltozások esetén

a myocardialis ischaemia csak kis myocardialis területekre lokalizálódik. endotheldependens vasodilatatio változásai: a NO-termelés és -kibocsátás kóros változásait invazív módszerrel a CBF és/vagy a CVRcsökkenés mutatja, intracoronariás acetilkolin adásakor. Noninvazív módon PET-tel mért myocardialis véráramlással $(\mathrm{MBF})$ vagy cold pressor teszt alkalmazásával vizsgálható. Az endotelindependens vasodilatatio károsodása pedig direkt hatású artériás vasodilatator (például adenozin, dipiridamol, papaverin) adásával mutatható ki a coronaria-véráramlás $(\mathrm{CBF})$ növekedése és/vagy a vascularis rezisztencia (CVR) csökkenése révén (2-4, 6-8, 15-19).

Extravasalis mechanizmusok: extramuralis kompresszió: ha megnó a szisztolés intramyocardialis és a ventricularis nyomás (például balkamra-hypertrophia) - csökken a myocardium perfúziója. Diasztolé megrövidülése: a diasztolé alatt csökken a coronariatelődés (CBF). Myocardiumoedema: myocarditisek, nyitott szívmútétek után is előfordulnak. Diagnózisa: kardioMR-rel $(2-9,17,18)$.

\section{Az MVD epidemiológiai adatai}

Az MVD minél szélesebb körú megismerése mellett szól, hogy előfordulása meglepóen jelentôs: a különböző invazív adatok alapján a nonobstruktív coronariabetegeknél 30-60\%-ra tehetô. A legnagyobb betegszámú invazív vizsgálat Patel és munkatársai tanulmányában található. 398978 betegből $69,6 \%$ volt hypertoniás, $26 \%$ diabeteses. A betegek $37,6 \%$-a volt obstruktív coronariabeteg, nonobstruktív 39,2\% volt, ezeknél 20\%-nál kisebb stenosis volt az összes érben. Kisebb esetszámú tanulmányokban: $42 \%$ MVD volt (ennek 70\%-a nőbeteg), 36\%-nál obstruktív, más vizsgálatokban a nonobstruktív forma $30 \%$-ban, illetve 50-65\%-ban fordult eló $(2-4,10,15-18)$.

\section{Rizikófaktorok}

\section{Kor}

60 év felett a koszorúér-áramlás fokozatos csökkenése mutatható ki, melynek oka valószínúleg az emelkedett szisztolés vérnyomás okozta szívterhelés, 70 év felett pedig a hyperaemia alatti áramlás csökkenése mutatható ki PET-tel $(2-4,10,19)$.

\section{Dohányzás}

Közvetlenül toxikus az endothelsejtekre, valamint a füstben lévô szabadgyökök növelik az oxidált LDL mennyiségét és csökkentik a NOkibocsátást. Tünetmentes dohányosoknál PETCT-vel a coronariaáramlási tartalék (CFR) 21\%kal kisebb a kontrollokéhoz képest, mely normalizálódik a dohányzás elhagyása után 1 hónappal $(2-4,20)$.

\section{Hypertonia és MVD}

A hypertonia a leggyakoribb és legnagyobb független rizikófaktora a cardiovascularis eseményeknek. Randomizált tanulmányok szerint a hypertonia kezelése kedvezően befolyásolja a cardiovascularis kimenetelt. Tekintve a hypertonia incidenciáját (a lakosság 34-37\%-a) és kóroki szerepét a coronariabetegségek és szövődményeinek elôidézésében, melyet a hypertoniás szívbetegség új klinikai entitásában foglalnak össze, ennek általános, különösen kardiológiai alulreprezentáltsága miatt, ezt részletesebben ismertetjük.

Az MVD, mint a hypertoniás szívbetegség egyik manifesztációja, cardiovascularis oldalról a szívnek a megnövekedő artériás nyomásra és a megnövekedett teljes perifériás rezisztenciára adott speciális válaszaként határozható meg. $\mathrm{Az}$ MVD patofiziológiai alapját a kedvezôtlen hemodinamikai elváltozások jelentik, ezeket követik a biológiai elváltozások, melyekhez nem hemodinamikai faktorok is társulnak, melyek kedvezőtlen strukturális átépüléshez vezethetnek - ezeket korábban már ismertettük. Ezen túlmenôen, a kor, a nem, a genetikai adottságok, az elhízás, a túlzott sófogyasztás, az inzulinrezisztencia, számos neuroendokrin tényezô (angiotenzin II, aldoszteron, szimpatikus tónus, endotelin), valamint hemoreológiai faktorok (vérviszkozitás, plazmavolumen). A CFR csökkenését mutatták ki hypertoniában, szekunder balkamra-hypertrophiában szenvedő betegekben obstruktív epicardialis koszorúér-betegség hiányában is. A hypertonia fennállásának az idôtartama, a súlyossága jelentôs szerepet játszik a CFR csökkenésében. A CFR károsodása nem 
szükségszerúen korrelál a bal kamrai tömeggel. Ugyanakkor az intramuralis microvascularis remodelling és az endothel-rendellenességek, valamint a RAAS aktivációja fontosabb szerepet játszhat a hypertoniával társuló CMVD patogenezisében, mint a balkamra-hypertrophia. A hypertoniás szívbetegség valószínúleg különféle genetikai determinációk alapján alakul ki, ezek azonban még pontosan nem ismertek $(2-5,10$, $14,17,18,21-23)$.

\section{Nemi eltérések - nóbetegek MVD-je}

Ellentétben a korábbi állásponttal, a nonobstruktív coronariabetegség, különösen nők esetében, jelentősebb mortalitással jár, mint az obstruktív forma. A férfiakéhoz viszonyított nagyobb mortalitásban a magasabb életkor, a rizikófaktorok halmozódása, a szubklinikai atherosclerosis, a fokozott vazoreaktivitás, az érrendszeri átalakulás nemi különbségei, a posztmenopauzális állapot, a gyulladásos markerek emelkedett szintje, a reproduktív hormonszintekben történő változás, a generalizált vascularis károsodások, a Raynauld-fenomén, az autoimmun artériás betegségek, a társbetegségek nagyobb száma játszhatnak szerepet. A rosszabb prognózist a diagnosztika és a kezelés hiányosságai is magyarázzák (1-4, 10, 17, 24-28).

\section{Hyperlipidaemia}

Tünetmentes hyperlipidaemiás nonobstruktív betegeknél a CFR csökkenése korrelációban volt az össz- és LDL-koleszterin-szinttel, több megfigyelés megerősíti az LDL-frakció endotheldiszfunkciót okozó szerepét $(2-4,10,17,29-31)$.

\section{Obesitas}

Csökkent hyperaemiás MBF-válasz tapasztalható a nem elhízottakhoz képest, az endotheliumtól függó koszorúér-vasodilatatio romlik (2-4, 10, 17, 29-31).

\section{Diabetes mellitus}

Az endothelialis diszfunkció miatt a károsodott CFR-t mind az 1-es, mind a 2-es típusú diabeteses betegekben kimutatható többszörös dinamikus képalkotási módozatokkal, CT, MRI és stressz/nyugalmi PET képalkotással. A diffúz epicardialis atherosclerosisban és/vagy MVDben szenvedő cukorbetegeknek hasonló prognózisuk lehet, mint az obstruktív epicardialis coronariabetegeknek. Itt is kiemelendő a hypertonia szerepe: az egyidejúleg magas vérnyomásban szenvedő betegekben a CFR még tovább csökken $(1-4,10,17,24-27,29,31)$.

\section{Inflammatorikus és egyéb tényezők}

Az inflammáció az atherosclerosis releváns rizikófaktora, aminek fontos szerepe van az MVD kialakulásában is. Negatív hatásúak az endothelialis sejtekre a gyulladásos citokinek, a CRP, az interleukin 6, a tumornekrózis-faktor- $\alpha$, valamint kedvezőtlen hatásúak a NO-szintetáz és a NO-kibocsátás gátlására. Nôk esetében ehhez még egyéb tényezôk is társulnak $(2-4,10,17,23$, $26-28,30)$.

\section{Elsődleges stabil microvascularis angina (MVA) (obstruktív coronariabetegség és egyéb myocardialis betegség nélküli forma)}

Meghatározás: nyugalomban vagy terhelésre létrejövő anginás rosszullétek obstruktív coronariabetegség (koronarográfiával ép epicardialis erek és/vagy 50\%-nál kisebb stenosis) és egyéb myocardialis betegség nélkül (normális regionális globális balkamra-funkció, nincs egyéb jele myocardialis vagy szisztémás betegségnek), ahol a myocardialis ischaemia és a mellkasi fájdalom oka a CMD (okait, a rizikófaktorokat korábban, a bevezetô részben ismertettük). A coronaria-X-szindróma (CSX) egy gyakran használt diagnosztikai kifejezés a nonobstruktív coronariabetegeknél, a CSX diagnózisát azonban az irodalomban liberálisan alkalmazzák, jelentôs különbségek vannak a meghatározásai között, a hátterében valószínúleg CMD áll $(2-4,10,17,32-34)$.

\section{Diagnosztika}

A hazai gyakorlat számára rövid diagnosztikus algoritmust ismertetünk az 1. táblázatban.

\section{Panaszok, tünetek}

A beteg panaszai - angina - alapján nem lehet elkülöníteni, mivel az MVD és az obstruktív coronariabetegség okozta angina klinikai képe hasonló lehet.

\section{Az MVD okozta angina pectoris jellemzői}

Nyugalomban: atípusos, hosszan tartó nyomó mellkasi fájdalom, vagy diszkomfort, vagy szúró, változó időtartamú mellkasi fájdalom, vagy típu- 


\section{1. táblázat. Tennivalók a hazai klinikai gyakorlatban microvascularis angina gyanújakor}

\section{A beteg alapvizsgálatai}

Első vizsgáló (háziorvos, kezelőorvos) által javasoltak

Ischaemiás tünetek

$\downarrow$

Anamnézis - rizikófaktorok

$\downarrow$

Fizikális vizsgálat

$\downarrow$

Nyugalmi EKG (pozitív-negatív)

$\downarrow$

Minden esetben kardiológiai kivizsgálás

Kardiológus által javasoltak

Noninvazív vizsgálatok

Funkcionális képalkotás

A vizsgálatok sorrendje a helyi (hazai)

- Echokardiográfia: transthoracalis (TTE)

elérhetőségek szerint:

1. Echokardiográfia: TTE-TEE

2. Terheléses EKG

3. SPECT és/vagy CCTA

transoesophagealis (TEE)

- Terheléses EKG (TEKG)

- Szívizotóp-vizsgálat (SPECT)

4. CMRI-PET

- Myocardialis kontraszt echokardiográfia

- Myocardialis perfúziós képalkotás (MPI-SPECT)

- Coronaemissziós tomográfia (PET)

- Cardialis mágneses rezonancia (CMRI)

Figyelembe veendők, előnyös:

- Alacsony klinikai valószínúség

- A beteg adottságai, jellemzői jó képminôségre utalhatnak

- Helyi elérhetőség és tapasztalat

- Egyéb információ

- Nincs CAD-előzmény

$\uparrow \downarrow$

A vizsgálatok sorrendje a helyi elérhetôségek szerint

CCTA (Coronary Computed Tomography

Angiography - kardio-CT)

Az EAPCI-ajánlás alapján a hazai viszonyokra adaptálva.

sos angina pectoris - mely lehet nyugalmi (éjszakai) - egyaránt szerepelhetnek. NB: ezek hátterében a hypertoniabetegség általi vérnyomásemelkedés indukálta angina pectoris kizárása szükséges, egyidejû 24 órás ABPM és EKG-monitor alkalmazásával.

$\mathrm{Az}$ angina pectoris típusú fájdalom egyéb mellkasi fájdalmaktól való elkülönítésére egy néhány kérdésből álló anamnesztikus segédletet ismertetünk.

Mellkasi fájdalom - angina pectoris típusú:

- Mikor jelentkezik? Fizikai terheléskor (sietés, lépcsôzés); nyugalomban: vérnyomás-emelkedéskor, étkezéskor, hidegben, éjjel?

- Hol jelentkezik? Mellkasközépen, nyakban, vállban, hátban?

- Milyen érzés? Szorító, markoló, nyomó, égő, ritkán szúró?

- Kisugárzása? Nyakba, karba, vállba, állkapocsba, molaris fogba, hátba?

- Megszúnése? Terhelés abbahagyásakor, vérnyomáscsökkentésre, melegben, nitroglicerinre perceken belül?

Terhelésre: angina, ezzel egyenértékú a nehézlégzés, de az MVA okozta anginára az is jellemzô, hogy a fájdalom még percekig fennáll a terhelés megszúnte után. Nemcsak edzés közben alakulhat ki, hanem túlnyomórészt az edzés utáni helyreállási idôszakban is (amikor egyensúlyhiány áll fenn a szív oxigénigénye és a kínálat között).

Nitrátra vagy csak kis mértékben, vagy egyáltalán nem reagál az MVA (rövid és tartós hatásúra egyaránt) $(2-4,6,10,17,21-23,33-35)$.

\section{A hypertonia indukálta nyugalmi angina pectoris jellemzői}

A beteg panaszai között atípusos mellkasi fájdalom, mellkasi diszkomfortérzés, valamint típusos angina pectoris (nyugalmi vagy effort) egyaránt szerepelhetnek. Fő jellemzője a jelentôs vérnyomás-emelkedés, melynek következtében változhat az anginaküszöb. Ez 24 órás egyidejú vérnyomás (ABPM) és EKG- (Holter-) monitoros vizsgálattal (Cardiotens, CardXplore készülékek) diagnosztizálható. A nem hypertoniás beteg angina pectorisa esetében a vérnyomás-emelkedés csekélyebb mértékú (160/100 Hgmm alatti), de tapasztalataink szerint anginiform mellkasi fájdalommal reagálhatnak ennél kisebb mértékú vérnyomás-emelkedésre olyan fiatalabb diabeteses, mozgásszegény életmódú, obes nőbetegek, akiknél szimpatikus idegrendszeri túlsúly is észlelhe- 
tő. A hypertonia indukálta nyugalmi angina pectorist kísérheti nehézlégzés, verejtékezés, palpitáció - szapora szívverés -, mely aritmiás is lehet, ennek oka leggyakrabban extraszisztólia, ritkábban supraventricularis tachycardia vagy pitvarfibrilláció $(2-4,6,10,21-23,35)$.

\section{A hypertonia indukálta effort típusú angina pectoris jellemzői}

$A z$ anginaküszöb változékonysága jellemzi: a hypertonia és a következtében kialakult perifériás vascularis rezisztencia növekedése, esetleges a vasoconstrictiv tényezők miatt a vérnyomásemelkedéskor a szív terhelése megnó - egy szúkebb csőrendszeren kell ugyanazon vérmenynyiséget áthajtani -, ezért a szív munkája és oxigénigénye a vérnyomás-változástól, -emelkedéstől függően változó mértékben megnő, ezért a szívizom-ischaemia mértéke sem állandó. Ez magyarázza a hypertoniás beteg effort anginájának anginaküszöb-változékonyságát, szemben a klasszikus, stabil, effort anginás beteg állandó anginaküszöbével, ahol az anginát azonos mértékú tevékenység váltja ki, azonos mértékú, és azonos helyen érzett fájdalom jön létre, mely pihenésre mindig hasonló módon szúnik. Hypertoniás beteg esetében éppen a hypertonia fent leírt modifikáló hatása következtében időszakonként változik az anginaküszöb. Jellemzô erre, hogy a beteg elmondása szerint bizonyos idószakokban a fizikai terhelést kiválóan bírja, máskor, a vérnyomás-emelkedésekhez kapcsolódóan gyakori az idójárás hidegfronti vasoconstrictor szerepe - angina pectorissal reagál egy relatíve kisebb terhelésre is, amennyiben ez jelentôs vérnyomásemelkedéssel is jár $(2-6,10,21-23,33,35)$.

Tekintettel az MVA klinikai megjelenésének nagy változatosságára, a Coronary Vasomotion Disorders International Study Group (COVADIS) egységes diagnosztikai kritériumokat határozott meg az MVA felismerésére. Ezek a következôk: 1. a myocardialis ischaemia tünetei; 2 . az obstruktív coronariabetegség hiánya; 3. a myocardialis ischaemia objektív bizonyítéka; 4 . a microvascularis diszfunkció bizonyítéka (36) (2. táblázat).

\section{Vizsgálómódszerek}

Invazív koronarográfia és az alkalmazott mérések (indexek) értelmezése

Lehetôvé teszi, hogy megítéljük az epicardialis koszorúerek betegségének a jelenlétét és súlyosságát. Az intervenciós kezelésről (PCI vagy a
2. táblázat. A microvascularis angina gyanújának klinikai diagnosztikai kritériumai

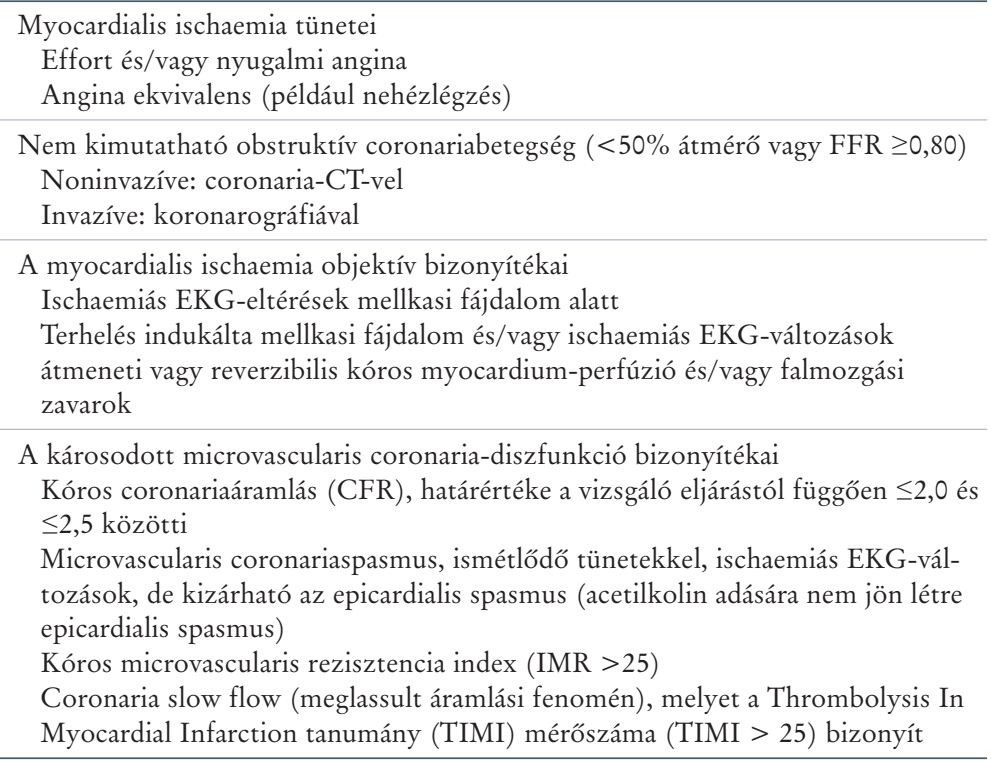

A Coronary Vasomotion Disorders International Study Group (COVADIS) alapján (36).

koszorúérbypass-mútét, $\mathrm{CABG}$ ) a döntés a közelmúltig csak a koronarogram vizuális értékelésén alapult. Az EAPCI és ESC ajánlása alapján, de a hazai gyakorlatban is ez pontatlan lehet, mert egyrészt az anatómiai szúkület súlyosságának a megítélése szubjektív, másrészt a vizuálisan súlyosnak látszó szúkületek jelentôs része (akár 60-80\%-a) a coronariaáramlást nem, vagy alig korlátozza, ami téves funkcionális diagnózishoz és helytelen kezelési döntésekhez vezethet $(2,15)$.

A szívkoszorúér-szúkület súlyossága és a laesioszintú ischaemia invazív módon értékelhetô a szívizom frakcionális áramlási tartaléka alapján [FFR = nyugalmi distalis koszorúérnyomás $(\mathrm{Pd})$ és aortanyomás $(\mathrm{Pa})$ aránya $(\mathrm{Pd} / \mathrm{Pa})]$, valamint az intracoronariásan adott értágító gyógyszer (például dipiridamol, adenozin) által előidézett maximális szívizom-hyperaemia. Az FFR $\leq 0,80$ az a bizonyítékokon alapuló küszöbérték, amely obstruktív koszorúér-betegségre utal, és amelynél előnyös lehet a revascularisatio. FFR > 0,80 értékénél a revascularisatio helyett konzervatív terápia javasolt. Az FFR-mérése nagy diagnosztikai pontossággal képes azonosítani és kizárni az obstruktív coronariabetegséget. A coronariakeringés patofiziológiájának jobb megismerésére, valamint az obstruktív és a microvascularis coronariabetegség elkülönítésére is alkalmas az FFR-rel kombinált CFR alkalmazása. Az FFR-vezérelt koszorúér-beavatkozás a 0,80 FFR-küszöbérték alkalmazásával csökkenti a szívkoszorúér-revascularisatiók számát a vizuális értékelésú angiográfiával irányított koszorúér- 
beavatkozásokhoz képest, különösen elônyös többérbetegeknél, a kedvező klinikai kimenetel mellett $(1-4,10,15,17,32,35-40)$.

A coronariaáramlási tartalék (coronaria flow reserve, CFR) a globális coronariakeringés mérésének indirekt paramétere mind az epicardialis, mind a microvascularis erekben. Coronaria flow reserve $=$ maximális hyperaemiás áramlás / basalis áramlás, $\mathrm{CRF}=\mathrm{CBF} / \mathrm{MBF}$. Normális értéke nagymértékben függ a meghatározásához alkalmazott technikától, de a legtöbb publikáció úgy véli, hogy a CFR <2,0 kellóen kóros ahhoz, hogy ischaemia alakuljon ki $(1-4,10,17$, $32,35-40$ ).

Invaziv diagnosztika az FFR és a CFR egyezése/eltérése alapján: 1. mindkettô normális értéke nem utal obstruktív és microvascularis betegségre; 2. egyidejû́ kóros FFR és CFR obstruktív betegségre utal; 3 . a normális CFR és a csökkent FFR elsôsorban lokális, körülírt, de az áramlást nem korlátozó epicardialis betegségre utal; 4. csökkent CFR és normális FFR esetében domináns MVD vagy diffúz koszorúér-atherosclerosis áll fenn. Összehasonlítva a párhuzamos normális eredményekkel, a normális FFR és a rendellenes CFR együtt jár a súlyos cardiovascularis események fokozott kockázatával, míg normális CFR és a csökkentett FFR esetében nem (1-4, 10, 17, 32, 35-40).

A microvascularis rezisztencia index (IMR) a microvascularis coronariák múködésének felmérésére alkalmas, krónikus stabil coronariaszindrómában és akut myocardialis infarktusban, amelyekben prognosztikai jelentôsége van. Feltételezve, hogy a szívkoszorúér-áramlás és a szívizomáramlás egyenló, és a járulékos áramlás elhanyagolható, akkor: IMR = distalis koszorúérnyomás/koszorúér-áramlás. Az IMR $<20$ a normális tartomány, az IMR > 30 emelkedett értékú, azaz microvascularis diszfunkcióra utal $(1-4,10,17,32,35-40)$.

\section{Noninvazív módszerek}

\section{Nyugalmi EKG}

A repolarizációs zavar (ST-szakasz-, T-hullám-eltérések) alapján nem különíthetô el egyértelmúen az MVD. Az ST-eleváció többnyire obstruktív coronariabetegségre utal $(1-4,10,17,32,34,41)$.

\section{Terheléses EKG}

Jól ismert a terheléses EKG kis szenzitivitása miatti korlátozott diagnosztikus értéke, pozitív esetben ischaemiát bizonyító értékú, negatív eset- ben nem zárja azt ki. Hazai viszonyok között minden anginagyanús, kis-közepes kockázatú betegnél (a pretesztvalószínúség > 15\%) javasolt a terheléses EKG. Coronariabetegség gyanújakor, negatív terheléses EKG-teszt után, az ESC ajánlásának megfelelően, a coronariabetegség igazolására a CCTA alkalmazandó $(1-4,10,17,32,34,41)$.

\section{Echokardiográfia}

Transthoracalis echokardiográfia (TTE): nyugalmi formájában a szöveti Dopplerrel (TDI) mért E/E' 15 feletti értéke utalhat MVD okozta emelkedett bal kamrai töltónyomásra. TTE vagy transoesophagealis echokardiográfia (TEE) módszerú stressz-echokardiográfiában a bal elülsô leszálló coronariaartériában (left anterior descendent, LAD) mért CBF csökkenése, a dipiridamollal végzett kétdimenziós (2D) és háromdimenziós (3D) stressz-echokardiográfia során a globális longitudinális strain csökkenése utalhat MVD-re. A kontraszt echokardiográfia szemikvantitatív módszer a bal kamrai szegmentumok perfúziójának a megítélésére. A mikrobuborékos kontrasztanyag mellékhatásai miatt kevésbé alkalmazzák $(1-4,10,17,32,35,41)$.

\section{SPECT (Single Photon Emission Computed Tomography)}

Közismert elnevezése: szívizotóp-vizsgálat. A véráramlás kvantitatív meghatározása ultragyors, nagy érzékenységú kamerákkal, a tallium $\left({ }^{201} \mathrm{Tl}\right)$ alkalmazása felülmúlja a technéciummal $\left({ }^{99 \mathrm{~m}} \mathrm{Tc}\right)$ jelölt nyomjelzőket, a ${ }^{201} \mathrm{Tl}$ kedvezóbb nyomjelzô tulajdonságai alapján. A hibrid rendszerekben (SPECT-CT) rekonstruálás során együtt regisztrált CT-képek a legpontosabb áramlási becslést nyújtják a dinamikus SPECT-vizsgálatokban $(1-4,10,17,32,35,41)$.

\section{CCTA (Coronary Computed Tomography Angiography)}

A CCTA közismert elnevezése: kardio-CT. A korszerú CCTA szkennerek elegendô térbeli felbontással rendelkeznek az endocardium és az epicardium meghatározására, lehetőséget adnak, hogy a koszorúerek egyes területeihez kapcsolódó regionális myocardialis perfúziót becsülhessük a nagy erek kontrasztjának számítási modellezésével. A szívizom-ischaemia igazolására további noninvazív lehetôségek az úgynevezett hibrid képalkotó módszerek: a CCTA és SPECT egyidejư alkalmazása, valamint a SPECT, PETCT, de ezek elérhetôsége még a CCTA-nál is korlátozottabb $(1-4,10,17,32,35,41-44)$. 


\section{PET (pozitronemissziós tomográfia)}

A PET a noninvazív eljárások között kiemelkedő szenzitivitású és specificitású az MVD diagnosztikájában, az MBF mérésében $(1-4,10,17,32$, $35,41)$.

\section{CMR (kardiomágneses rezonancia)}

A CMR a myocardialis perfúzió felmérésével a CMD különböző klinikai formáinak diagnózisára alkalmas: beleértve az aszimptomatikus magas rizikójú egyéneket, elsődleges (például hypertoniás szívbetegség) és másodlagos MVD-MVA-t (HCM, Tako-tsubo) és revaszkularizált betegeket $(1-4,10,17,32,35,41)$.

\section{Az elsődleges MVD, MVA kezelése}

A kezelés elveit röviden a 3. táblázat ismerteti.

\section{Rizikófaktorok eliminálása}

Általában célszerú figyelembe venni, hogy bármelyik kockázati tényezó kezelésének elönyei nemcsak a jövőbeli betegség abszolút kockázatától függenek, hanem attól is, hogy melyik jelzett kockázati tényezô milyen mértékben járul hozzá a betegség kockázatához.

Hypertonia kezelése: az ACE-gátlók és az ARB-k normalizálhatják az endotelindependens microvascularis funkciót. A Ca-blokkolók között a dihidropiridineknek nincs ilyen hatásuk, míg a verapamilnak van. A $\beta$-blokkolók közül a nebivolol és carvedilol kedvezô hatású az endothelfunkcióra, míg a metoprolol és atenolol nem.

Hyperlipidaemia: tekintve az LDL-koleszterin-frakció endotheldiszfunkciót okozó szerepét, teljes lipidprofil kezelése szükséges, nem csak egyedül az összkoleszterinszinté. A statinok javíthatják az endothelfunkciót, de erról nincsenek evidenciák.

Diabetes: a normoglykaemia elérése szükséges.

Obesitas: a testsúlycsökkentés javította a CBF-t, ami korrelált az adiponektinszint növekedésével.

Mozgásszegény életmód: a cardialis statusnak megfelelô rendszeres aerob és rezisztencia mozgásformák (gyors gyaloglás, kocogás, kerékpározás, súlyzózás stb.) a kollaterális keringés növekedésével javíthatja a microvascularis keringést.

Élvezeti szerek: a dohányzás, a drogok és a rendszeres alkoholfogyasztás, utóbbi a kisérkárosodások miatt, a hypertonia egyik rizikófaktora, oka lehet $(2-4,10,17,45)$.

\section{3. táblázat. Az INOCA (MVD-MVA) kezelése a gyakorlatban}

1. Nem gyógyszeres kezelés: életmód-változtatás

- Egészséges táplálkozás

- Adagolt, adaptált kardiotréning

- Testsúlyredukció

- Dohányzás: -

- Alkoholfogyasztás: -

- Stressz csökkentése relaxációs módszerekkel

2. Rizikófaktorok kezelése

- Hypertonia

- Hyperlipidaemia

- Diabetes

3. Antianginás gyógyszeres kezelés

Micro-

vascularis angina

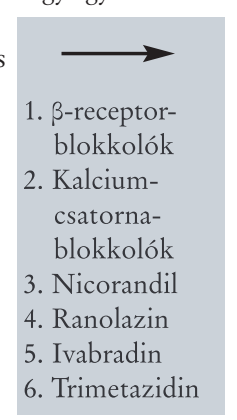

Statin, ACEI-
és ARB-kezelés
megfontolása

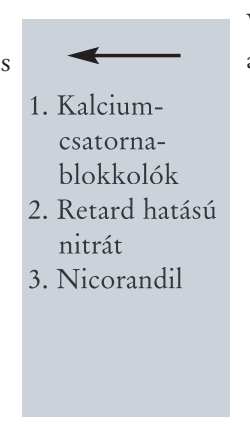

Vasospasticus angina

Kalcium-

Retard hatású nitrát Nicorandil

EAPCI után módosítva.

\section{Az elsődleges stabil MVA kezelése}

A kezelés fő célja a tünetek megszüntetése és a cardialis szövődmények megelőzése-csökkentése. Az antiischaemiás kezelés az elsôdleges, de bizonyos betegeknél nem mindig hatásos. Ezért a kezelésre nem reagálóknál alternatív kezelési eljárások javasoltak. Nincsenek egyértelmú evidenciák a kis esetszámú tanulmányok miatt.

\section{Hagyományos antiischaemiás szerek}

ß-receptor-blokkolók elsősorban a kardioszelektív, vasodilatator típusúak: nebivolol, carvedilol ajánlottak.

Kalcium-csatorna-blokkolók: amlodipin és verapamil javasolt.

Nitrátok: MVA-ban kevésbé hatásosak, mint obstruktív epicardialis coronariabetegségben, vagy amikor a szívizom-ischaemiát az epicardialis coronariaerek spasmusa okozza, a gyors hatásúak akut tünetek enyhítésére változó hatásfokkal adhatók, a krónikus adagolás kedvezô hatására nincsen bizonyíték.

\section{Egyéb antiischaemiás szerek}

Xantinszármazékok: intravénásan adott aminophyllin (mint adanozinantagonista) csökkentette az effort anginákat, ST-eltéréseket, fájdalomcsökkentő hatása is van a fájdalmat fokozot- 
4. ábra. Elsödleges akut MVA - az MVD okozta akut coronariaszindróma differenciáldiagnózisa

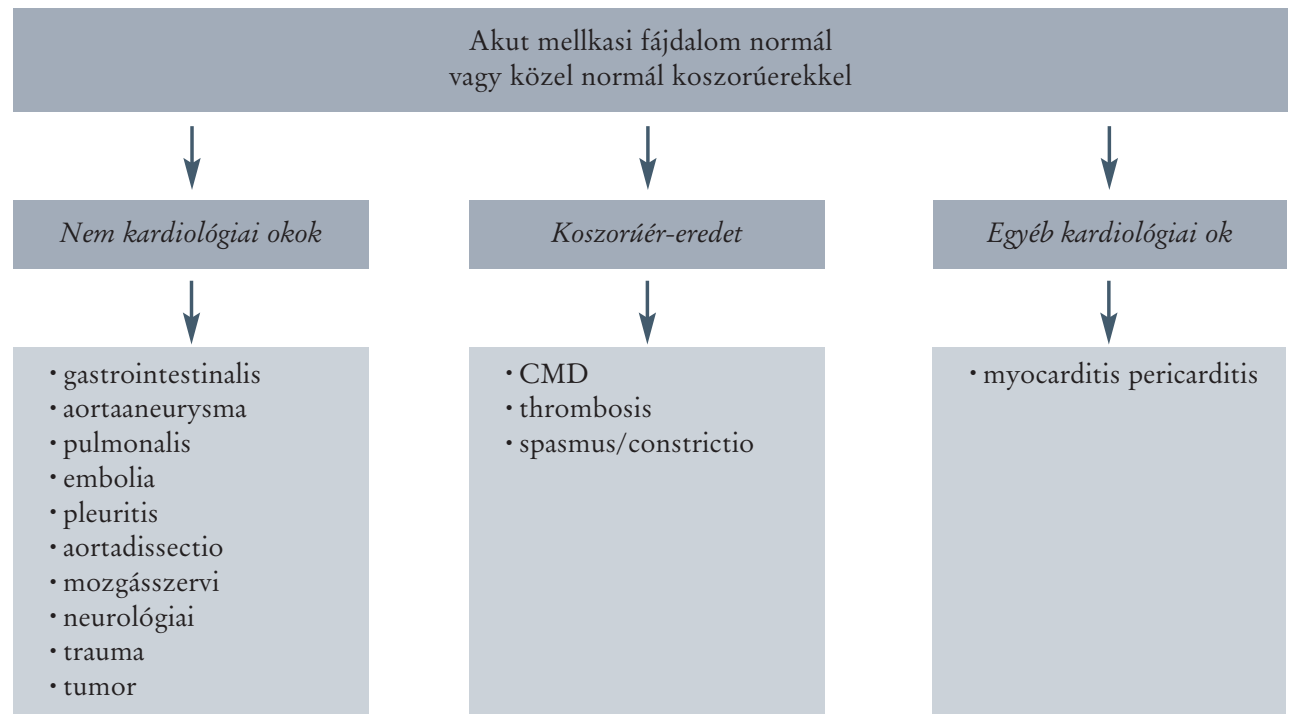

Crea után módosítva.

tabban megélő betegeknél. A tartós gyógyszerelés hatékonyságára nincs elegendő bizonyíték.

$A C E$-gátlók (enalapril, ramipril) és $A R B-k$ (irbesartan) különösen hypertonia esetében javították a CFR-t.

1-receptor-antagonisták: az emelkedett szimpatikus tónus miatti $\alpha 1$-receptorok közvetítette vasoconstrictiót csökkentve mérséklődik a mellkasi fájdalom, és az ischaemiás epizódok száma, valamint javulhat a terhelési tolerancia (doxazosin, prazosin).

Nicorandil: közvetlen nitrátszerú dilatatív hatású, ha a nitrát nem hatásos, akkor adható.

Trimetazidin: hatása kedvező lehet a terheléses kapacitás növelésében és az ST-depresszió csökkentésében, de nem egyértelmúen hatásos.

Ranolazin: a késő́i nátriumbeáramlás gátlása csökkenti a myocyták intracelluláris Ca-túlterhelését, ischaemiában javítva a diasztolés funkciót. Hatékony MVA-ban és obstruktív coronariabetegségben is.

Ivabradin: a szinuszcsomó-aktivitás csökkentésével, bradikardizálva növeli a diasztolé idejében a coronariatelödést. Kevés adat van MVAbeli pozitív hatásáról, míg obstruktív coronariabetegségben egyértelmúen hatásos.

Statinok: antioxidáns és antinflammatorikus hatásuk révén javítják az endothelfunkciót, hasznosak lehetne MVA-ban, különösen magas LDL-szintnél.

Ösztrogének: menopauzában az ösztrogénhiány patogenetikai tényező az endothelfunkció károsodásában, ezért MVA-ban ösztrogénhiány esetén adásuk javasolható (bár hosszú távú hatásuk nem egyértelmú).
Fájdalom megélését csökkentố gyógyszerek: $\beta$-blokkolók, aminophyllin, imipramin, esetleg egyéb szedatívumok $(3,4,10,17,45)$.

\section{Elsődleges akut MVA-MVD okozta akut coronariaszindróma}

Epidemiológiája: az akut mellkasi fájdalommal járó, nem ST-elevációs akut coronariaszindrómás (NSTE-ACS) betegek 5-10\%-ában észleltek koronarográfiával normális vagy közel normális (50\%-nál kisebb stenosis) coronariákat. Ezek közül mintegy $30 \%$ a nőbeteg. Mindezen esetekben a CMD felvethetô, ha az angina egyéb okát kizárták. Az elsődleges akut MVA differenciáldignózisát a 4. ábra ismerteti.

\section{Diagnózis}

EKG: Akut mellkasi fájdalom, a nyugalmi EKG-n ST- és/vagy T-eltérésekkel. Biomarkerek enyhe emelkedése (elsôsorban troponin, myoglobin). Koronarográfiával normális vagy közel normális coronariák, a vasoconstrictor ágensekkel (acetilkolin, ergonovin) nem kiváltható epicardialis coronariaspasmus utal MVA-ra. Nonivazív vizsgálatok: CCTA, MRI (lásd az előzó részben).

\section{Kezelés}

Mint akut coronariaszindróma és MVD esetében $(1-4,10,17,34,40)$. 


\section{MVD obstruktív coronariabetegségben}

Diagnózisa: károsodott hyperaemiás áramlás és CFR, FFR mérésével. Invazív módon: koronarográfia, noninvazív módon: myocardialis perfúzió vizsgálata képalkotó módszerrel (PET-CT, MRI). A fokális/diffúz coronariabetegség és MVD elkülönítése: az FFR és CFR konkordanciáján és diszkordanciáján alapul $(1-5,10,17,32$, $34,40)$.

\section{Iatrogén CMD}

Technikailag sikeres percutan coronariaintervenciók (PTCA-PCI) és szívsebészeti beavatkozások (ACBG) után ritkán jelentkezik, de kialakulhat a biomarkerek emelkedése által jelzett myocardialis károsodás. Ennek hátterében distalis occlusio vagy embolisatio állhat (utóbbi a vena saphena graft PCI-je után gyakoribb, mint a natív coronariákon). Diagnózisa: PCI után a troponin több mint 5-szöröse, az ACBG után több mint 10-szerese a referenciatartomány felsô határértékéhez képest a beavatkozást követő 48 órában, elhúzódó ischaemia jelei (több mint 20 percig tartó mellkasi fájdalom) és/vagy ischaemiás ST-eltérések, új patológiás Q-hullám megjelenése, az áramlás csökkenésének angiográfiás jelei, embolisatio, az életképes myocardium csökkenése vagy új falmozgási zavar kialakulása képalkotó módszerrel. A metaanalízisek eredményei arra hívják fel a figyelmet, hogy a stabil anginás betegeknél, kis myocardialis ischaemiás rizikó esetén, a PCI nem javítja a betegség kimenetelét, nincsenek evidenciák, melyek szerint a PCI a konzervatív kezelésnél jobban csökkentené a halálozás és a nem fatális infarktus kockázatát $(1-4,10,17,34,40)$.

\section{Másodlagos MVD egyéb kardiológiai betegségekben}

A másodlagos MVD okai lehetnek cardiomyopathiák: dilatatív cardiomyopathia (DCM), hypertrophiás cardiomyopathia (HCM); infiltratív szívbetegségek: Anderson-Fabry-betegség, amyloidosis; aortastenosis, myocarditis. Bármely esetben a microvascularis diszfunkcióra is utalhat a típusos vagy az atípusos angina. Az általános orvosi gyakorlatban ritka elófordulásuk miatt, valamint, miután a cardialis érintettség tekintetében a microvascularis diszfunkció iga- zolása speciális kardiológiai invazív és nonivazív vizsgálatokat igényel - ezek részletes ismertetésétől eltekintettünk $(1-4,10,17,34,40,46)$.

\section{Összefoglalás}

A microvascularis coronariabetegség és a hátterében álló microvascularis diszfunkció diagnosztikája és terápiája a betegség heterogenitása és a relatíve kevés rendelkezésre álló adat, evidenciák hiányában igen összetett, bonyolult, idő- és költségigényes feladat. Az elsődleges MVD-MVA felismerésére a meghatározott, egységes diagnosztikai kritériumok figyelembevétele szükséges. Hangsúlyozni kell, hogy ez a kórkép súlyához képest még mindig jelentősen alulreprezentált, diagnosztizálása, megfelelő kezelése jelenleg nem megfelelő a hazai orvosi gyakorlatban sem. Ennek okai részben a szemléletbeli hiányosságok: kevéssé közismert, hogy a kezeletlen MVD éppoly - különösen nőkben gyakoribb - súlyos szövődményekhez (szívinfarktus, szívelégtelenség stb.) vezethet, mint az obstruktív coronariabetegség. Nem megfelelöen ismert a nonobstruktív ischaemiás szívbetegség terápiás stratégiája, az ajánlott kezelést nem megfelelő gyakorisággal alkalmazzák. Ezért is fontos, hogy anginás panaszok, hypertonia, pozitív terheléses EKG-teszt esetén "negatív” koronarográfia-lelet adásakor az MVD lehetôségére is felhívja a kardiológus a kezelőorvos figyelmét, és további noninvazív vizsgálatokat javasoljon vagy végeztessen. A MVD rosszabb prognózisa a diagnosztikai alulértékelés, a noninvazív eljárások kellő mértékú alkalmazásának a hiányából adódik. Ma már a noninvazív kardiológiai képalkotó eljárások fejlődésével a coronariaáramlás indexeinek a mérése is lehetôvé és egyre elterjedtebbé vált hazánkban is: például a noninvazív CTFFR meghatározása nagyobb diagnosztikus pontossággal rendelkezik a laesiospecifikus ischaemia azonosítását illetôen az invazív FFR-méréshez képest. A hazai gyakorlatban még mindig elsődlegesen alkalmazott terheléses EKG helyett érdemes az ESC ajánlása alapján az új preteszt-valószínúséget (PTP) figyelembe venni. Az utóbbinak szélesebb körú bevezetése azt is jelzi, hogy nem szükséges a betegeket rutinszerúen közvetlenül invazív kivizsgálásra irányítani, kivéve az MVD okozta akut coronariaszindróma gyanúja esetét, és/vagy, ha a klinikai vagy egyéb adatok nagymértékben utalnak az obstruktív coronariabetegségre. Invazív kivizsgálás esetén pedig mindig gondolni kell a nonobstruktív coronariabe- 
tegség esetén az MVD-re is, és az erre utalható indexek (CFR, FFR, IMR) mérésével lehetne a háttérben állható CMD-t igazolni. Jelenleg még a hazai viszonylatban ezek meghatározása a megfelelő szemlélet- és eszközhiány miatt gyakran elmarad. Az ajánlások szerinti noninvazív vizsgálatok (CCTA, PET, MRI) viszont egyre inkább elérhetőek.

\section{Irodalom}

1. Knuuti J, Wijns W, Saraste A, Capodanno D, Barbato E, et al. 2019 ESC Guidelines for the diagnosis and management of chronic coronary syndromes: The Task Force for the diagnosis and management of chronic coronary syndromes of the European Society of Cardiology (ESC). European Heart Journal.

2. Kunadian V, Chieffo A, Camici PG, et al. An EAPCI Expert Consensus Document on Ischaemia with Non-Obstructive Coronary Arteries in Collaboration with European Society of Cardiology Working Group on Coronary Pathophysiology \& Microcirculation Endorsed by Coronary Vasomotor Disorders International Study Group. Eur Heart J 2020;4 (37):3504-20.

https://doi.org/10.1093/eurheartj/ehaa503

3. Crea F, Camici PG, Merz CNB. Coronary microvascular dysfunction: an update. Eur Heart Journal 2014;35:1101-1. bttps://doi.org/10.1093/eurbeartj/ebt513

4. Taqueti V R, Di Carli MF. Coronary microvascular disease pathogenic mechanisms and therapeutic options: JACC state-of-the-art review. J Am Coll Cardiol 2018 Nov 27;72 (21):2625-41 https://doi.org/10.1016/j.jacc.2018.09.042

5. Picano E, Palinkas A, Amyot R. Diagnosis of myocardial ischemia in hypertensive patients. J Hypertens 2001;19: 1177-83.

https://doi.org/10.1097/00004872-200107000-00001

6. Bugiardini R, Merz CNB. Angina with "normal" coronary arteries. A changing philosophy. JAMA 2005;293:477-84. https://doi.org/10.1001/jama.293.4.477

7. Crea F, Lanza GA, Camici PG. Coronary microvascular dysfunction. Springer-Verlag Italia; 2014. p. 3-30. https://doi.org/10.1007/978-88-470-5367-0 1

8. Opie LH. The Heart. Phisiology and metabolism. New York: Raven Press; 1991. p. 52-65, 278-84.

9. Hoffman JI, Spaan JA. Pressure-flow relations in coronary circulation. Physiol Rev 1990;70:331-90. https://doi.org/10.1152/physrev.1990.70.2.331

10. Szauder I. A hypertoniás ischaemiás szívbetegség, microvascularis angina pectoris. In: Szauder I (szerk.). A hypertoniás szívbetegség monográfiája. Budapest: Vox Medica Kiadói Kft.; 2011. p. 93-111.

11. Bassenge E, Heusch G. Endothelial and neuro-humoral control of coronary blood flow in health and disease. Rev Physiol Biochem Pharmacol 1990;116:77-165. https://doi.org/10.1007/3540528806_4

12. Baumgart D, Haude $M$, Gorge $G$, et al. Augmented alphaadrenergic constriction of atherosclerotic human coronary arteries. Circulation 1999;99:2090-7. bttps://doi.org/10.1161/01.CIR.99.16.2090

13. Heusch G, Baumgart D, Camici P, et al. Alpha-adrenergic coronary vasoconstriction and myocardial ischemia in humans. Circulation 2000;101:689-94. https://doi.org/10.1161/01.CIR.101.6.689

14. Izzo $\operatorname{~r~} L$. The sympathetic nervous system in acute and chronic blood pressure elevation. In: Oparil S, Weber MA (ed). Hypertension. A Companion to Brenner and Rector's The Kidney 2nd ed. Philadelphia: Elsevier; 2005. p. 60-76. https://doi.org/10.1016/B978-0-7216-0258-5.50096-X

15. Patel $M r$, Peterson ED, Dai D, et al. Low diagnostic yield of elective coronary angiography. $N$ Engl J Med 2010;362:886-95. https://doi.org/10.1056/NEJMoa0907272

16. Safdar B, D’Onofrio G, Dziura J, et al. Prevalence and characteristics of coronary microvascular dysfunction among chest pain patients in the emergency department. Eur Heart J Acute Cardiovasc Care 2020;9(1):5-13. https://doi.org/10.1177/2048872618764418
17. Marinescu MA, Löffler AI, Onellette $M$, et al. Coronary microvascular dysfunction, microvascular angina, and treatment strategies. JACC Cardiovasc Imaging 2015;8:210-20. https://doi.org/10.1016/j.jcmg.2014.12.008

18. Crea F, Lanza GA, Camici PG. Coronary microvascular dysfunction. Springer-Verlag Italia; 2014. p. 31-47. https://doi.org/10.1007/978-88-470-5367-0_2

19. Uren NG, Camici PG, Melin JA, et al. Efffect of aging on myocardial perfusion reserve. J Nucl Med 1995;36:2032-6.

20. Morita K, Tsukamoto T, Naya $M$, et al. Smoking cessation normalizes coronary endothelial vasomotor response assessed with 15O-water and PET in healthy young smokers. $J$ Nucl Med 2006;47:1914-20.

21. Erdogan D, Yildirim I, Ciftci O, et al. Effects of normal blood pressure, prehypertension, and hypertension on coronary microvascular function. Circulation 2007;115:593-9. https://doi.org/10.1161/CIRCULATIONAHA.106.650747

22. Chim CL, Krum H. Lip GHY. Complications of hypertension: The Heart. in Cardiology (3rd ed). Mosby: Elsevier; 2010. p. 541-50.

23. Rimoldi $O$, Rosen SD, Camici PG. The blunting of coronary flow reserve in hypertension with left ventricular hypertrophy is transmural and correlates with systolic blood pressure. J Hypertens 2014;32:2465-71. https://doi.org/10.1097/HJH.0000000000000338

24. Johnson BD, Kelsey SF, Bairey Merz CN. Clinical risk assessment in women: chest dicomfort. Report from the WISE study. In: Shaw LJ, Redberg RF (ed.). CAD in Women: Evidence-Based diganosis and treatment. Totowa NJ: Humana Press; 2003. p. 129-42.

https://doi.org/10.1007/978-1-59259-645-4_10

25. Shaw LJ, Bairey Merz CN, Reis SE, et al. WITSE Investigators Ischemic heart disese in women: insights from the NHLBIsponsored Women's Ischaemia Syndroma Evaluation (WISE) Study. Part I.: sex differences in traditional and novel risk factors, symptom evaluation and gender optimized diagnostic strategies. J Am Coll Cardiol 2006;47:S4-520.

26. Shaw LJ, Bugiardini R, Merz NB. Women and Ischaemic Heart Disease: Evolving Knowledge.medscape.com/viearticel/710602. Published: JACC 10/30/2009.

27. Gulati $M$, Cooper-DeHoff RM, McClure C, et al. Adverse cardiovascular otucomes in women with nonobstructive CAD: a report from the from the NHLBI-sponsored Women's Ischemia Syndrom Evaluation (WISE) study and the St James Women take Heart (WTH) project. Arch Intern Med 2009;169. 843-50. https://doi.org/10.1001/archinternmed.2009.50

28. Lanza GA, Sesito A, Cammarota $G$, et al. Assessment of systemic inflammation and infective pathogen burden in patients with cardiac syndrome X. Am J Cardiol 2004;94:40-4. bttps://doi.org/10.1016/j.amjcard.2004.03.027

29. Prior JO, Quinones MJ, Hernandez-Pampaloni $M$, et al. Coronary circulatory dysfunction in insulin resistance, impaired glucose tolerance, and type 2 diabetes mellitus. Circulation 2005;111:2291-8.

bttps://doi.org/10.1161/01.CIR.0000164232.62768.51

30. Kovacs I, Toth J, Tarjan J, et al. Correlation of flow mediated dilatation with inflammatory marker sin patients with impaired cardiac function. Eur J Heart Fail 2006;8:451-9. https://doi.org/10.1016/j.ejheart.2005.10.011

31. Schindler TH, Cardenas J, Prior JO, et al. Relationship between increasing body weight, insulin resistance, inflammation, adipocytokine leptin, and coronary circulatory function. J Am Coll Cardiol 2006;47:1188-95. https://doi.org/10.1016/j.jacc.2005.10.062

32. Feher A, Sinusas AJ. Quantitative Assessment of Coronary Microvascular Function: Dynamic SPECT, PET, Ultrasound, 
CT and MR Imaging. Circ Cardiovasc Imaging 2017; 10(8): e006427 https://doi.org/10.1161/CIRCIMAGING.117.006427

33. Lanza GA, Manzolo A, Bia E, et al. Acute effects of nitrates on exercise testing patients with syndromea $\mathrm{x}$. Clinical and pathophysiological implications. Circulation 1994; 108:1263-77.

34. Fibn SD, Gardin JM, Abrams J, et al. 2012 ACCF/AHA/ ACP/AATS/PCNA/SCAI/STS guideline for the diagnosis and management of patients with stable ischemic heart disease: a report of the American College of Cardiology Foundation/American Heart Association. Circulation 2012;126 (25):e354-471.

35. Schindler TH, Dilsizian V. Coronary microvascular dysfunction. Clinical considerations and noninvasive diagnosis. JACC: Cardiovascular Imaging 2020;13:140-55. https://doi.org/10.1016/j.jcmg.2018.11.036

36. Ong P, Camici PG, Beltrame JF, et al. International standardization of diagnostic criteria for microvascular angina. Int J Cardiol 2018;250:16-20. https://doi.org/10.1016/j.ijcard.2017.08.068

37. Crea F, Lanza GA, Camici PG. Coronary microvascular dysfunction. Springer-Verlag Italia; 2014. p. 63-7. https://doi.org/10.1007/978-88-470-5367-0

38. De Bruyne B, Pijls NH, Kalesan B, et al. Fractional flow reserve-guided PCI versus medical therapy in stable coronary disease. N Engl J Med 2012;367(11):991-1001. https://doi.org/10.1056/NEJMoa1205361

39. Fearon WF, Bornschein B, Tonino PA, et al. Economic evaluation of fractional flow reserve-guided percutaneous coronary intervention in patients with multivessel disease. Circulation 2010;122(24):2545-50. bttps://doi.org/10.1161/CIRCULATIONAHA.109.925396
40. Amsterdam EA, Wenger NK, Brindis RG, et al. 2014 AHA/ ACC guideline for the management of patients with non-STelevation acute coronary syndromes: a report of the American College of Cardiology/American Heart Association Task Force on Practice Guidelines. Circulation 2014; 130:e344-426.

41. Crea F, Lanza GA, Camici PG. Coronary microvascular dysfunction. Springer-Verlag Italia; 2014. p. 49-63. bttps://doi.org/10.1007/978-88-470-5367-0

42. Donnelly PM, Kolossvary M, Karady J, Maurovich-Horvat P, et al. Experience with an on-site coronary computed tomography-derived fractional flow reserve algorithm for the assessment of intermediate coronary stenoses. Am J of Card 2018;121:9-13. https://doi.org/10.1016/j.amjcard.2017.09.018

43. Maurovich Horvat P. A szív komputer-tomográfiás vizsgálatának új klinikai perspek-tívái. MTA Doktori Értekezés Tézisei, 2018. p. 19-27. https://mta.hu/doktori-tanacs/folyamatban-levodoktori-eljarasok-105296.

44. Koo B-K, Erglis A, DobJ-H, et al. Diagnosis of ischemiacausing coronary stenoses by noninvasive fractional flow reserve computed from coronary computed tomographic angiograms. Results from the prospective multicenter DISCOVER-FLOW (Diagnosis of Ischemia-Causing Stenoses Obtained Via Noninvasive Fractional Flow Reserve) study. Am Coll Cardiol 2011;1> 58(19):1989-97.

45. Crea $F$, Lanza GA, Camici PG. Coronary microvascular dysfunction. Springer-Verlag Italia; 2014. p. 195-218. https://doi.org/10.1007/978-88-470-5367-0 8

46. Crea F, Lanza GA, Camici PG. Coronary microvascular dysfunction. Springer-Verlag Italia; 2014. p. 115-37. https://doi.org/10.1007/978-88-470-5367-0

\section{GONDOLATOK A LAM-BÓL I 30 ÉVE ÍRTÁK}

„....Az október 15-i ülést, - amelyen a miniszter, a Bizottság, s a hallgatói önkormányzatok vezetôi vettek részt (a SOTE részéról e sorok íó́ja) - az tette időszerúvé, hogy a legtöbb egyetemen a továbblépés lehetetlennek látszik. A cél ugyanis az egyetemi tanácsok tagságának és szervezetének megváltoztatása, de ebhez a régi egyetemi tanácsok beleegyezése kell. Jogilag egyelöre "ök" a legitim fórumok, maga alatt pedig érhetöen, senki nem vágja a fát. A paradox helyzet feloldására az ülés résztvevoói konszenzusra jutottak a következókben:

A jelenlegi egyetemi tanácsok jogkörét szúkiteni kell: ne azok legyenek jogosultak az új Egyetemi Alkotmányok elfogadására és a választás lebonyolítására. Ugyanakkor jöjjön létre egy "Alkotmányozó gyúlés", amelyben valóban demokratikusan választott küldöttek vannak. Ez az intézmény, amely megfelelhet egy összegyetemi oktatói-hallgatói küldött-közgyúlésnek, lesz hivatott legitimálni az új SzMSz-t és az új vezetést.

Nem más ez a jelenség, mint az a bizalmatlanság, bizalmi válság, amely az ország közéletét is áthatja. Bibó István gondolatával élve, akkor harmonikus egy ország politikai (ön) tudata, ha a jogositványokkal felrubázott emberek nem élnek maradéktalanul jogaikkal, és biztosak abban is, hogy a másik, akinek szintén jogai vannak (méghozzá szabályozó, ellenôrzố, sót visszahivási jogai), csak akkor fogja ezeket használni, ha "én" okot szolgáltatok rá.

A jelenlévök mind egyetértettek abban, hogy elóbb kell megalkotni az Alkotmányokat és ezután ennek alapján lebonyolítani a választásokat. ... A négy egyetem mindegyikében az Alkotmány egyébként 90\%-ig készen van. ... Nemsokára sikerül az intézetekhez és a HÖKhöz "társadalmi vitára" átadnunk...

Végezetül Surján László népjóléti miniszter, úgy érzem, elsősorban a négy jelen lévő hallgatóhoz szólva emlékeztetett, hogy ... kész a párbeszédre. A problémákat elöre tisztázzuk, mintbogy félreértések adódjanak a hiányos információáramlásból.

Nemes Balázs SOTE”

Nemes B. Hogyan alakuljon át az orvosegyetem? Lege Artis Medicinæ, Próbaszám, 1990. december: 62. o. 